\title{
BUSANA KERAJAAN TOKOH GATOTKACA WAYANG KULIT PURWA GAYA SURAKARTA
}

\author{
Rafika Fidelia, Dendi Pratama \\ Program Studi Desain Komunikasi Visual \\ Fakultas Bahasa dan Seni Universitas Indraprasta PGRI \\ Jl. Nangka No.58c, Tanjung Barat, Jakarta Selatan, 12530 \\ alambudiansya@gmail.com
}

\begin{abstract}
Abstrak
Gatotkaca merupakan salah satu tokoh yang ada dalam pewayangan Jawa, ksatria yang gagah perkasa. Dalam wayang kulit purwa gaya Surakarta Gatotkaca digambarkan seorang raja muda. Hal itu terlihat pada bentuk busana dan atribut yang digunakan Gatotkaca. Busana dan atribut tersebut memiliki fungsi dan makna seperti untuk menjelaskna kedudukan seorang tokoh. Metode penelitan yang digunakan adalah metode kualitatif, dengan membaca dari sumber likuitatif, observasi, dan melakukan wawancara dengan narasumber.
\end{abstract}

Kata Kunci : Wayang Kulit Purwa Gaya Surakarta, Gatotkaca, Busana

\begin{abstract}
Gatotkaca is one of the characters in the Javanese puppet, a mighty knight. In the Surakarta style of puppet, a viceroy is described. This can be seen in the form of clothingand attributes used by Gatotkaca. Clothing and attributes have functions and meanings such as to explain the position of a character. The research method used is a qualitative method, by reading from literary sources, observing, and interviews with sources.
\end{abstract}

Keywords : Purwa Gagrak Surakarta Puppets, , Gatotkaca, Clothing

\section{PENDAHULUAN}

Gatotkaca adalah seorang ksatria yang cekatan, saat berperang kekuatannya sangat cepat, sakti mandraguna. Gatotkaca merupakan anak dari Werkudara yang berasal dari keluarga Pandawa dan ibunya Dewi Arimbi yang berasal dari bangsa raksasa.

Gatotkaca memiliki julukan "otot kawat, tulang besi". Dalam bentuk wayang kulit Gatotkaca menggunakan pakaian kerajaan, dikarenakan Gatotkaca merupakan seorang raja muda yang berasal dari Negeri Pringgadani. Setiap bentuk busana dan atribut yang terdapat pada wayang kulit memiliki makna dan fungsi, seperti simbol kedudukan dari seorang tokoh.

Artikel ini membahas tentang busana dan atribut dari tokoh Gatotkaca pada wayang kulit gaya Surakarta yang dilihat dari elemen-elemen visual pada boneka wayang. Elemen-elemen visual tersebut berupa bentuk-bentuk busana dan atribut wayang. Gatotkaca tak hanya mengunakan busana yang dapat terlihat atau tampak oleh mata saja. Selain itu, Gatotkaca memiliki busana dan atribut yang tidak tampak, semua itu merupakan hadiah dari Batara Guru. Busana tersebut berupa Caping Basunanda, Kotang Antrakusuma, dan terompah Pandakacarma.

\section{METODE PENELITIAN}

Metode penelitian yang digunakan dalam artikel ini adalah kualitatif, bersumber dari membaca referensi baik berupa buku, artikel, atau pun jurnal yang terkait dengan tokoh Gatotkaca 
maupun wayang kulit gaya Surakarta.

Observasi melihat secara langsung bentuk wayang kulit Gatotkaca, serta melakukan wawancara dengan Bambang Suwarno sebagai dalang dan pekria wayang kulit.

\section{PEMBAHASAN}

Kisah kelahiran Gatotkaca dikisahkan secara tersendiri dalam pewayangan Jawa. Namanya sewaktu masih bayi adalah Jabang Tetuka (Kaelola dalam Widyokusumo, 2010:188189). Waktu dilahirkan Tetuka berupa raksasa; karena sangat saktinya, tidak ada senjata yang dapat memotong tali pusarnya.

Kemudian tali pusar itu dapat juga dipotong oleh sarung senjata Karna yang bernama Konta, tetapi sarung senjata itu masuk ke dalam perut Tetuka, dan menambah lagi kesaktiannya (Kaelola dalam Saptodewo, 2013: 242). Versi pewayangan Jawa melanjutkan, waktu berjalan dari hari berganti hari, bulan berganti bulan. Bambang Tetuka sekarang telah dapat berjalan dan sangat lincah. Dan Batara Narada mengatakan bahwa sudah waktunya untuk Tetuka.

Kata-kata itu membuat Bimasena heran dan bertanya apa maksudnya. Dijelaskanlah oleh Batara Narada kalau dirinya membawa tugas untuk meminjam Bambang Tetuka untuk membantu para dewa membasmi keangkaramurkaan Prabu Kalapracona (Kaelola dalam Saptodewo, 2013: 242).

Dengan kehendak Dewa-Dewa, Tetuka itu dimasak sebagai bubur dan diisi dengan segala kesaktian; karena itu nantinya Raden Gatotkaca berurat kawat, bertulang besi, berdarah gala-gala, dapat terbang diawan dan duduk diatas awan yang melintang. Kecepatan Gatotkaca pada saat terbang diawan sebagai kilat, liar sebagai halilintar (Hardjowirogo dalam Saptodewo, 2013: 242).

Tetuka kemudian bertarung dengan Patih Sekipu dan berhasil membunuhnya menggunakan gigitan taringnya. Kresna dan Pandawa saat itu datang menyusul ke kahyangan. Kresna kemudian memotong taring Tetuka dan menyuruhya berhenti menggunakan sifat-sifat kaum raksasa (Kaelola dalam Saptodewo, 2013: 242-243). Batara Guru raja kahyangan menghadiahkan seperangkat pakaian pusaka, yaitu Caping Basunanda, Kotang Antrakusuma, dan terompah Pandakacarma untuk dipakai Tetuka, yang sejak saat itu diganti namanya menjadi Gatotkaca.

Dengan menggunakan pakaian pusaka tersebut, Gatotkaca mampu terbang secepat kilat menuju Kerajaan Trabelasuket dan membunuh Kalapracona (Kaelola dalam Saptodewo, 2013: 243). Dalam bahasa Sansekerta, nama Gatotkaca secara harafiah bermakna "memiliki kepala seperti kendi". Nama ini terdiri dari dua kata, yaitu ghat(tt)am yang berarti "buli-buli" atau kendi dan utkacha yang berarti "kepala".

Nama ini diberikan kepadanya karena sewaktu lahir kepalanya konon mirip dengan bulibuli atau kendi (Kaelola dalam Saptodewo, 2013: 243). / Gambar 1. Sketsa transformasi Bambang Tetuka. (Sumber: F. Saptodewo, 2015) Bentuk boneka wayang Gatotkaca dalam wayang kulit gaya Surakarta digambarkan sebagai berikut: / Gambar 2.

Boneka wayang Gatotkaca (Koleksi: Bambang Soewarno. Foto: Fidelia, 2018) Dari fisiknya Gatotkaca bermata telengan (membelalak), berhidung dempak, berkumis dan berjenggot. Berjamang tiga susun, bersunting waderan, bersanggul kadal menek, bergaruda membelakang, berpraba, berkalung ulur-ulur, bergelang, berpontoh dan berkeroncong. Berkain kerajaan lengkap, (Hardjowirogo dalam Saptodewo, 2015: 24).

Dalam bentuk tersebut terdapat simbol-simbol yang juga menjelaskan status Gatotkaca yang merupakan seorang raja muda di Negeri Pringgadani. Menggantikan sang ibu, Dewi Arimbi. Maka dari itu Gatotkaca menggenakan busana kerajaan lengkap. Struktur bagian dari wayang kulit ini dibagi menjadi tiga yaitu, bagian kepala, bagian badan, dan bagian kaki.

Pada tiap bagian tersebut melekat berbagai busana dan atribut yang memiliki makna sebagai simbol atau perlambang dari kekuasaan. Busana kerajaan yang digunakan oleh Gatotkaca antara lain jamang 3 susun, garuda mungkur, praba, kalung ulur-ulur, gelang, kelat bahu, kuncan yang merupakan busana bagian bawah seorang raja, uncal kencana, uncal wastra, dan juga binggel atau yang biasa dikenal gelang kaki. Jamang / Gambar 3. 
Jamang Gatotkaca (Koleksi: Bambang Soewarno. Foto: Fidelia, 2018) / Gambar 4. Sketsa Jamang (Foto: Fidelia, 2018) Gatotkaca menggunakan jamang tiga susun, dengan susunan segitiga yang bersusun ke atas. Jamang merupakan ikatan kepala apabila tokoh tidak menggunakan mahkota. Hanya kalangan raja yang menggunakan jamang bersusun tiga.

Tiga susun bermakna awal, tengah, dan akhirnya kehidupan yang menggambarkan tentang kesempurnaan hidup. Garuda mungkur / Gambar 5. Garuda Mungkur Gatotkaca (Koleksi: Bambang Soewarno. Foto: Fidelia, 2018) / Gambar 6. Sketsa Garuda Mungkur (Foto: Fidelia, 2018) Gatotkaca mengenakan hiasan garuda mungkur.

Hiasan yang melekat pada bagian belakang gelung atau mahkota, biasanya dikenakan oleh golongan raja, ksatria, para punggawa dan juga patih. Garuda mungkur dapat menolak marabahaya yang berasal dari arah belakang. Praba / Gambar 7. Praba Gatotkaca (Koleksi: Bambang Soewarno. Foto: Fidelia, 2018) / Gambar 8. Sketsa Praba (Foto: Fidelia, 2018) Praba merupakan hiasan yang terletak pada punggung wayang yang diikatkan pada bahu.

Praba merupakan lambang singgahsana, maka biasanya digunakan oleh raja atau patih yang besar. Dan juga praba tersebut diikat oleh tali praba yang terletak pada dada boneka wayang. Kalung / Gambar 9. Kalung Gatotkaca (Koleksi: Bambang Soewarno. Foto: Fidelia, 2018) / Gambar 10.

Sketsa Kalung (Foto: Fidelia, 2018) Kalung yang merupakan hiasan pada leher dapat meunjukkan tingkat jabatan dari tokoh wayang, yang digunakan Gatotkaca berbentuk kalung ulur-ulur karangrang. Yang merupakan lambang dari seorang raja. Gelang / Gambar 11. Gelang Gatotkaca (Koleksi: Bambang Soewarno. Foto: Fidelia, 2018) / Gambar 12.

Sketsa Gelang (Foto: Fidelia, 2018) Aksesoris gelang hiasan yang berada ditangan pada wayang dapat menentukan kedudukan dan karakter tokoh wayang tersebut. Gatotkaca menggunakan Gelang Kana Calumpringan, dikenakan tokoh pendeta, raja dan juga ksatria. Kelat Bahu Gatotkaca / Gambar 13. Kelat Bahu Gatotkaca (Koleksi: Bambang Soewarno. Foto: Fidelia, 2018) / Gambar 14.

Sketsa Kelat Bahu (Foto: Fidelia, 2018) Kelat bahu hiasan yang digunakan pada bagian lengan, menunjukkan juga status sosial dari pemakainya. Kelat bahu yang dipakai Gatotkaca adalah Naga Memangsa atau Naga Rangsang adalah kelat bahu yang biasa dipakai oleh raja-raja. Kuncan / Gambar 15. Kunca Gatotkaca (Koleksi: Bambang Soewarno. Foto: Fidelia, 2018) / Gambar 16.

Sketsa Kuncan Foto: Fidelia, 2018) Kuncan merupakan busana bagian bawah untuk pakaian kerajaan. Kuncan terdapat beberapa elemen-elemen busana untuk membedakan dengan tokoh wayang yang bukan seorang raja. Uncal kencan___a dan wastra / Gambar 17. Uncal kencana dan wastra Gatotkaca (Koleksi: Bambang Soewarno. Foto: Fidelia, 2018) / Gambar 18. Sketsa uncal kencana (Foto: Fidelia, 2018)/Gambar 19.

Sketsa uncal wastra (Foto: Fidelia, 2018) Uncal ada dua macam, yaitu uncal kencan dan uncal wastra. Uncal wastra atau selendang dan uncal kencana berbentuk wajik memanjang dan menggantung di sekitar kaki. Gatotkaca memakai uncal kencana dan wastra. Yang membedakan tokoh raja dengan lainnya ialah terdapat pada uncal wastra. Pada tokoh biasa tidak menggunakan uncal wastra hanya menggunakan uncal kencana.

Binggel / Gambar 20. Binggel Gatotkaca (Koleksi: Bambang Soewarno. Foto: Fidelia, 2018) / Gambar 21. Sketsa Binggel (Foto: Fidelia, 2018) Binggel atau gelang kaki bisa menentukan kedudukan dan karakter dari tokoh yang memakainya. Binggel yang digunakan Gatotkaca adalah kroncong yang berbentuk dhapur nagaraja.

Busana tidak tampak Gatotkaca Busana Gatotkaca secara wujud tak hanya pada wujud yang terlihat atau tampak oleh mata tetapi terpadat pula busana yang tak tampak. Busana yang tampak seperti yang sudah disebutkan. Sedangkan, yang tidak tampak merupakan pakaian pusaka yang diberikan kepada Gatotkaca sebagai hadiah karena sudah membantu para dewa.

Ada tiga pakaian pusaka yang dimiliki oleh gatotkaca yaitu: Caping Basunanda, merupakan penutup kepala yang membuat Gatotkaca mampu merasa kepanasan jika terkena panas dan tidak basah ketika hujan. Kotang Antrakusuma, baju yang membuat Gatotkaca mampu 
terbang dengan sangat cepat dan tampa tumpuan walau tanpa menggunakan sayap. Terompah Padakacarma, sepasang alas kaki yang membuat Gatotkaca akan terlindungi dari pengaruh jahat dari suatu tempat yang dia lewati, sehingga dia bebas melintasi tempat-tempat angker atau bahaya.

Dengan ketiga pakaian pusaka tersebut semakin menambah kesaktian dari Gatotkaca yang sudah terkenal dengan julukan "otot kawat, tulang besi". Membuat Gatotkaca mampu melakukan serangan dari udara.

\section{SIMPULAN}

Wayang bukan hanya sebatas tontonan, melainkan cerminan kehidupan manusia seharihari. Tergambar pula pada busana dan atribut yang terdapat pada bentuk wayang kulit.

Di dalam busana dan atribut pada wayang kulit dibuat bukan hanya sekedar untuk memperindah bentuk wayang kulit tersebut. Busana dan atribut dari wayang kulit pun memiliki makna dan fungsinya. Contohnya adalah untuk menjelaskan kedudukan seorang tokoh. Dengan lebih mengenal tentang busana dan atribut dari wayang kulit diharapkan dapat lebih membangun keinginan untuk terus mengenal tentang budaya wayang kulit, sehingga ikut membantu melestarikan budaya Indonesia.

\section{DAFTAR PUSTAKA}

Saptodewo, F. (2015). Kajian mitologi dan dekonstruksi Tokoh wayang tetuka. DEIKSIS, 5(03), 239-250.

Saptodewo, F. (2016). Perancangan bentuk tokoh wayang tetuka Saat balita. Jurnal Desain, 3(01), 21-26.

Widyokusumo, L. (2010). Kekayaan ragam hias dalam wayang kulit purwa gagrak surakarta (sebagai inspirasi desain komunikasi visual). Humaniora, 1(2), 402-414. 